\title{
Agriculture 4.0: Building Aquaponics System Using Solar Power Adapt to Climate Change in Vietnam
}

\author{
An The Huynh ${ }^{1,2 *}$, Yi-Ching Chen ${ }^{1}$ \\ Department of Environmental Engineering, Da-Yeh University, Changhua, 51591 Taiwan $^{1}$ \\ Department of Management Science, Thu Dau Mot University, Binh Duong, Vietnam²
}

\begin{abstract}
The world is on a constant momentum of development, creating new opportunities, but at the same time, there are many challenges presented. One of the most serious challenges that people need to face is climate change. Agriculture is the sectors most affected by climate change. Climate-Smart Agriculture will achieve its goals of food security, minimizing climate change effects. For Vietnam, the application of agriculture 4.0 is the application of the achievements of Industry 4.0 (Internet, biotechnology, nanotechnology, lighting technology, robotics ...) to agriculture in order to reduce labor, reduce losses due to natural disasters, pests, environmental safety, save costs in each stage or the whole production - processing - consumption process. Aquaponics system using solar energy is suitable for places with a lot of sunshine, soil is scarce and lack of water resources. This is exactly the case in Vietnam, where water resources are becoming increasingly scarce, only stored in lakes for the main purpose of hydropower. Using an aquaponics system can deal with the water problems that are taking place in many localities, especially in the midlands and mountainous areas. In this system, fish and vegetables will be grown in the same circulatory system. Fish eat food and generate waste, bacteria that will convert fish waste from the aquarium to a form of organic nutrients suitable for plants to grow. Water from the aquaculture system will be transferred into the hydroponic system. Therefore, the waste in the water will be converted by microorganisms into nutrients for plants to absorb again to grow. The water, after being cleaned by the plants in the hydroponic system, returns to the aquaculture system, ending a closed process. In comparison with the conventional aquaculture, the excretions and leftover food from animals can accumulate and increase the toxin in the water; The use of chemical fertilizers in farming affects the environment and people's health negatively; Considering the benefits of the Aquaponics system: namely fresh fish and clean vegetables, safe water, antibiotic-free fish, safe for health, etc, are outweighed the traditional agriculture. In addition, helping investors save production costs, improve product quality, reduce environmental pollution towards modern green agricultural production.
\end{abstract}

Keywords: Agriculture 4.0, Aquaponics system, Solar power, Climate change, Vietnam.

\section{INTRODUCTION}

The environment we live in is currently severely polluted from soil, water, air, and even light, ... The condition has been at an alarming level for a long time and now it is almost irreversible when human is still not self-aware of its harm. Environmental pollution causes many economic and health consequences and more notably causes global climate change, which is a great threat to humanity

Climate change includes both the global warming driven by human emissions of greenhouse gases, and the resulting large-scale shifts in weather patterns. Though there have been previous periods of climatic change, since the mid-20th century, humans have had unprecedented impact on Earth's climate system and caused change on a global scale until today (Wikipedia, 2020a).

Climate changes causes the economic losses and restrains the economic growth in many countries, including Vietnam. Research results of the United Nations recently announced that by 2030 the global economy could lose more than $\$ 2,000$ billion due to climate change and global warming. Data of the non-governmental organization Oxfam (UK) shows that the developing economies can lose up to 1,700 billion USD / year by 2050 (UNEP,2020).

In Vietnam, over the past 50 years, the average temperature has risen by about $2-3{ }^{\circ} \mathrm{C}$ and the sea level has risen by about $20 \mathrm{~cm}$. It is estimated that by the end of the $21 \mathrm{st}$ century, compared to the 1980-1999 average, the average temperature in Vietnam may increase by $2.3^{\circ} \mathrm{C}$, the annual rainfall will increase by about $5 \%$ and the sea level may rise. 75cm (MONRE, 2012). 


\section{International Advanced Research Journal in Science, Engineering and Technology}

Vol. 8, Issue 1, January 2021

\section{DOI: $10.17148 / I A R J S E T .2021 .8105$}

As an agricultural country (agriculture contributes about $20 \%$ of GDP), most of the poor depend on agriculture and fishing, so Vietnam is rated as one of the top 5 countries by the United Nations Development Organization. The world's most vulnerable and directly vulnerable to climate change processes. With the agriculture still heavily dependent on nature today, Vietnam needs to proactively assess and forecast the impacts of climate change, in order to promptly have appropriate and sustainable responses and develop the agricultural economy firm (Wikipedia, 2020b).

The effects of climate change on Vietnam's agriculture are not only on domestic food security but also on food security in the region and in the world, because Vietnam is one of the exporting countries the world's largest rice. Therefore, Vietnam needs to develop climate-smart agriculture to ensure food security and reduce greenhouse gas emissions; at the same time well adapting to the impacts of climate change $(\mathrm{Vu}, 2015)$

Aquaponics is a smart agriculture system that uses solar power to produce sustainable food that combines an aquaculture such as fish and combine with hydroponics in a symbiotic environment. In the aquaculture, effluents accumulate in the water, increasing toxicity for the fish. This water has led to a hydroponic system where the by products from the aquaculture are filtered out by the plants as vital nutrients, after which the cleansed water is recirculated back to the animals. The term aquaponics is a portmanteau of the term's aquaculture and hydroponic. Aquaponic systems vary in size from small indoor or outdoor units to large commercial units, using the same technology as shown in Fig. 1. The systems usually contain fresh water, but salt water systems are plausible depending on the type of aquatic animal and which plants. Aquaponics consists of two main parts, with the aquaculture part of raising aquatic animals and the hydroponics part of growing plants. The biofilter and hydroponic components can be combined by using plant support media such as gravel or sand that also functions as biofilter media. Raft hydroponics, which consists of floating sheets of polystyrene and net pots for plant support, can also provide sufficient biofiltration if the plant production area is large enough. Combining biofiltration with hydroponics is a desirable goal because eliminating the expense of a separate biofilter (Mohamand et al., 2013). Besides, combining with renewable energy is a good replacement for current energy source. Vietnam is suitable for producing energy through solar panel because it is located near the equator. Thus, the solar panel is the ideal green energy for power for aquaponics system. Besides providing electricity for people to use. With the government's policy of encouraging electricity purchase, farmers can sell the unused excess electricity to the Power Company. Therefore, here are also some factors to apply this clean energy source to generate additional income for farmers.

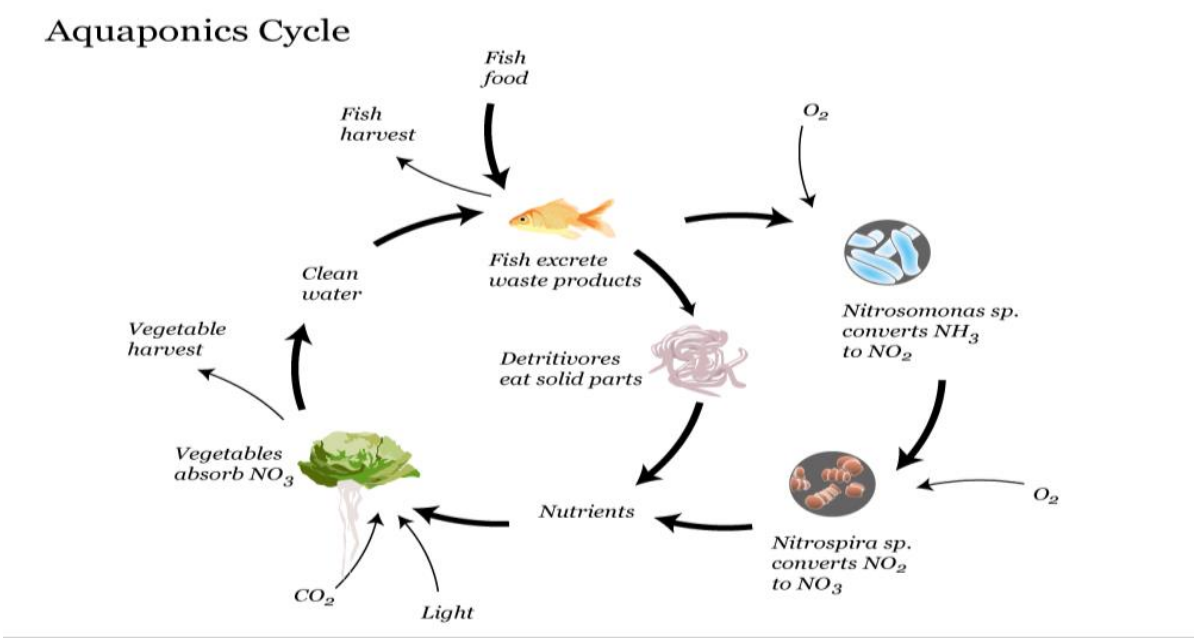

Fig 1. The Aquaponis Cycle (Visually, 2020)

Therefore, a research topic about building aquaponics system using solar power to adapt to climate change in Vietnam is an urgent issue. The aquaponics system using solar power will help people solve the problem when there is not enough electricity to meet irrigation capacity for agricultural production because it is located far away from the national power grid. Especially in remote areas, the power grid has not been drawn or the power source is unstable or cut off frequently. The implementation of the system is to minimize the process of climate change, protect the environment in agricultural production activities and work towards the green and clean sustainable agriculture. 
Vol. 8, Issue 1, January 2021

\section{DOI: $10.17148 / I A R J S E T .2021 .8105$}

\subsection{Materials}

\section{MATERIALS AND METHODS}

A plastic tank with a capacity of about 100-400L, Keramzit light gravel, used as a growing medium in plastic containers, an aquarium pump using AP 2000, PVC pipe 21, tube T, 1 inner thread 21, 1 outer thread 21, about $20 \mathrm{~cm}$ tube 21 to collect water, 1 tube T type 34-21-34, 3 units of 34 and 1 collection cone 34-21, Media substrate - Use a light Keramzit gravel as a substrate, a $\mathrm{pH}$ tester, and depending on the $\mathrm{pH}$ level available in the water tank, then use the tester to adjust $\mathrm{pH}$ level suitable for farmed fish - Use a pH pen.

Other tools: Drill; drill bit 6, wood cutters 20, wrench for screw 13 - the size of the screw for the iron shelf, solar panels

Sample preparation of fish and vegetables: Snakehead fish (Channa sp), and red tilapia (Oreochromis sp), and the vegetables experimental are: watercress lettuce (Nasturtium officinale L).

\subsection{Methods}

2.2.1. Aquaponics system design:

\section{Step 1: Install water tanks and shelves}

Place the water tank and assemble the iron bars into steel shelves. Note that the lowest floor of the vegetable pots should be at least $30 \mathrm{~cm}$ higher than the water tank. Put plastic trays to grow vegetables on the vegetable growing platform.

\section{Step 2: Install the water line up}

Install the water pump pumped up from the pump with PVC pipe 21, use the shrinks to bend the angle, use T-tubes to divide water at branch lines leading to different vegetable platforms. Design water pipes running along the rows of pots on the shelves, using a 6-diameter drill and then drilling 2-3 holes in the pipe so that when the water is pumped up, it will irrigate the vegetable pots.

\section{Step 3: Install the drain down}

- Install a drain line in each pot: Use a 20-diameter drill to make a circular hole at the bottom of each pot, install a pair of internal and external threads into the hole just pierced to create a drain down for each pot. Note the outer thread placed on the top of the perineum, the inner thread is placed on the bottom of the perineum, reinforce the melt to avoid water leakage later. After you have installed the drain, we can also use the pot's plastic net as a strainer.

- Installation of main drainage shaft for each vegetable floor: On each vegetable floor with different heights, install a PVC 34 spindle, combined with T 34-21-34 water pipes to collect water from pots to pipes spindle.

- Install a water rise and fall system on the vegetable barrel with a timer: The mechanism of bringing water up and down helps to support microorganism's growth by providing enough oxygen and necessary ventilation into the substrates. Using a drainage line at the bottom of the planting bin, drainage capacity is slower than the pump's water supply capacity (even drainage capacity is only $1 / 4-1 / 10$ of the feed line). Install the pump on the timer, set the pump cycle to $45 \mathrm{p} / 1$ cycle.

\section{Step 4: attached solar panels}

Installed according to section 2.2.2. Solar panel installation method

\section{Step 5: Trial operation}

Before bringing plants and fish to grow, do a test run to make sure the system is working as designed. All mistakes can be overcome a lot easier than when put into operation.

\section{Step 6: Finish}

Sprinkle light gravel into plant pots, keep the mesh of the plastic trays to help filter the dirt to avoid clogging the pumps and water pipes - Pebbles are used to create environments for nitrate bacteria biochemistry proliferates, transforms ammonia into nitrite and nitrite to nitrate.

Aeration pumps and air ducts - Pumps used to oxygenate both the aquarium and vegetable growing platform. The gas pipe is connected from the pump to the gas effervescent rock at the bottom of the tank. The aerated rock breaks down the air bubbles created by the pump into tiny bubbles, increasing the oxygen supply to the water tank.

Use litmus paper or measuring system, $\mathrm{pH}$ meter to check the $\mathrm{pH}$ of water. The ideal $\mathrm{pH}$ for an aquaponics aquarium is around 7.0. If it runs to level 7.2, it should lower it, but if it is below 6.8, it must be adjusted to high. Leave the system in place for 24 hours to ensure all chlorine in the water is dispersed.

Plant the seedlings in pots that have prepared seedlings by planting in peat pimples in advance. 


\section{International Advanced Research Journal in Science, Engineering and Technology}

Vol. 8, Issue 1, January 2021

\section{DOI: $10.17148 / I A R J S E T .2021 .8105$}

\subsubsection{Solar panel installation method:}

\section{Step 1: Erect the back panel and the base frame of the panel}

Frame size is determined by the number and layout of cells in each panel. If each cell has a voltage of about $0.5 \mathrm{~V}$ and plan to build a battery producing $18 \mathrm{~V}$ voltage, need all 36 cells. That power is enough to charge devices using $12 \mathrm{~V}$ power. Proceed to cut the materials according to the above dimensions. Use glue or screws to attach the frame covers to the back panel. Then coat the back panel and base frame evenly with three layers of UV-resistant paint (if made of wood), then let the paint dry completely. Make sure the base frame fits snugly against the back panel.

\section{Step 2: Attach cells to solder wire}

Need to have small solder wire, soldering pen, solder aid to attach cells together. Join cells that have been welded into a string: If the panels are arranged in a structure of 4 vertical and 9 horizontal rows, the erect every 9 cells into a chain. In this step need to solder the residual solder wire from the front of cell 1 to the back of cell 2, solder the residual solder wire from the front of cell 2 to the back of cell 3 and so on gets a cell sequence. Place the cells in the framework of the TPT baseplate and join them together.

\section{Step 3: Attach the base frame to the case and put the cover for the panel}

Need to adjust the base frame to fit in the panel of the panel. Screw the base frame to the case carefully. Have two wires long enough to be pulled out the back of the panel to the external energy receptors. Install a deterrent on the conductor at the anode to prevent the self-discharge of energy at night, unless using the charge controller. Should check the panel to make sure it works best before you install the tempered glass. Finally, seal the gaps between the back panel, frame rim and the outer cover with silicone solder to make the panel completely protected.

\section{Step 4: Check the overview}

One of the factors to pay attention to is the location of the solar panel assembly. To maximize the efficiency of the solar power system, need to assemble it at an angle and choose the positions of the panels to best absorb sunlight for the whole day.

\section{RESULTS AND DISCUSSION}

We hope that the investigation, collection and synthesis of statistics as well as research results Aquaponics system using solar power will return results such as:

Fish raised in the aquaponics model will grow faster than in the control tank due to the biofiltration system, which helps the water quality to be significantly improved so the fish grow better. Do not use any chemicals or drugs to spray on vegetables, cure fish.

Encouraging communities to apply aquaponics in the culture process will reduce frequent water changes and save water resources. Moreover, the model is also a source of clean food: clean vegetables and fish to consumers. Especially, this is a suitable model for sustainable development and climate change adaptation.

The Aquaponics system of combining solar power in agriculture, this is a solution to make the most of the land area, create jobs, increase income in agricultural development, especially improvement. Improving the living environment by using solar panels to generate electricity, thereby contributing to minimizing negative impacts on the environment, in line with the direction and development trend of the world.

\section{CONCLUSION}

In the context of climate change, the world is facing three challenges: food security, water resources and energy security. The solar-power Aquaponics system has solved the three above challenges towards smart agriculture, adapt to climate change in Vietnam.

Aquaponics system using solar power is potential for running community systems applied to local fisheries, and runoff from rainwater and streams to save the energy required for the recirculation process. This technology is promising for the rural population, especially in densely populated countries such as Bangladesh, Nepal and Vietnam, where farmers have limited land to provide food with protein, minerals and vitamins for their family. Aquaponics technology will be a promise for all farmers, to provide clean, safe food for their families, and then to serve the society. In the coming time, the research team will proceed to build real models to test the effectiveness of the solution, and find ways to improve the system's performance. 


\section{International Advanced Research Journal in Science, Engineering and Technology}

Vol. 8, Issue 1, January 2021

\section{DOI: $10.17148 /$ IARJSET.2021.8105}

\section{REFERENCES}

[1]. Vu, T. T. T. (2015). Climate smart agriculture development in Vietnam. Journal of Economics and Development. 220, 21-30.

[2]. Nguyen, L.T., Nguyen, H. N., Trinh, C. D., Bui, D. T., Nguyen, H. P. (2015). Automation in Aquaponic sustainable food producing system. The 3rd National Conference on Condition and Automation-VCCA.

[3]. Ministry of Natural Resources and Environment (MONRE) (2012). Final report on environment of Vietnam 2012, Vietnam.

[4]. The United Nations Environment Programme (UNEP) (2020). United Nations framework convention on climate change and the Paris Agreement.

[5]. Ngo, V. H., Ngo, T. L, Phan, H. T. (2012). Climate Change Education in Secondary Biology. Materials for teachers and education administrators, Hanoi, Vietnam.

[6]. Tran, T. N. B., Ngo, T. D. H. (2019). Aquaponic: Model of fish farming in combination with growing vegetables. Adaptation to climate change in the Mekong Delta in Tra Vinh Province. 04(III), 15-18.

[7]. David, C. L., Michael, S. U., Laura, G. (2015). Energy and water use of a small-scale raft aquaponics system in Baltimore, Maryland, United States. Aquacultural Engineering. 68, 19-27.

[8]. Paudel, S. R. (2020). Nitrogen transformation in engineered aquaponics with water celery (Oenanthe javanica) and koi carp (Cyprinus carpio): Effects of plant to fish biomass ratio. Aquaculture. 520, 734971.

[9]. Daniel, R. L., Caspar, G., Hans, C. Huub, H. M. R., Daniela, B., Werner, K., Divas, K., Karel, J. K. (2018). Model-based management strategy for resource efficient design and operation of an aquaponic system. Aquacultural Engineering. 83, 27-39.

[10]. Nuwansi, K. K. T., Verma, A. K., Chandrakant, M. H., Prabhath, G. P. W. A., Peter, R. M. (2020). Optimization of stocking density of Koi carp (Cyprinus carpio var.koi) with gotukola (centella asiatica) in an aquaponics system using phytoremediated aquaculture wastewater. Aquaculture. $532,735993$.

[11]. Chen, P., Zhu, G., Kim, H. J., Brown, P. B., Huang, J. Y. (2020). Comparative life cycle assessment of aquaponics and hydroponics in the Midwestern United Sates. Journal of Cleaner Production. 275, 122888.

[12]. Harry, W. P., Ulrich, K., Samuel, A., Sebastian, M. S., Benz, K. (2019). Coupled Aquaponics Systems. Aquaponics Food Production Systems. 163-199.

[13]. Migle, J. S., Genovaite, L. (2021). Climate change concern, personal responsibility and actions related to climate change mitigation in EU countries: Cross- Cultural analysis. Journal of Cleaner Production. 281, 125189.

[14]. Forchino, A. A., Gennotte, V., Maiolo, S., Brigolin, D., Mélard, C., Pastres, R. (2018). Eco-designing Aquaponics: A case study of an experimental production system in Belgium. Procedia CIRP. 68, 546-550

[15]. Cerozi, B. S., Fitzisimmons, K. (2017). Phosphorus dynamics modeling and mass balance in an aquaponics system. Agricultural Systems. 153, 94-100.

[16]. Abusin, S. A. A., Mandikiana, B. W. (2020). Towards sustainable food production systems in Quatar: Assessment of the viability of aquaponics. Global Food Security. 25, 100349.

[17]. Witzel, O., Wilm, S., Karimanzira, D., Baganz, D. (2019). Controlling and regulation of integrated aquaponic production systems - An approach for a management execution system (MES). Information Processing in Agriculture. 6(3), 326-334.

[18]. Klerkx, L., Rose, D. (2020). Dealing with the game-changing technologies of Agriculture 4.0: How do we manage diversity and responsibility in food system transition pathways. Global Food Securrity. 24, 100347.

[19]. Sayan, K. R., Debashis, D. (2020). Genetic Algorithm based internet of precision Agricultural things (IopaT) for Agriculture 4.0. Internet of Things.

[20]. Arunima, K. (2020). Understanding the differences between climate change deniers and believers' knowledge, media use, and trust in related information sources. 47(!), 101986.

[21]. Goddard, S., Busaidi, A.S. Al., Kendi, U.K. Al. (2010). Fish Culture and

Hydroponics at Low Salinities. A Monograph on Management of Saltaffected Soil and Water for Sustainable Agriculture. 89-94.

[22]. Ismaili, A.M. Al., Jayasuriya, H. (2016). Seawater Greenhouse in Oman: A Sustainable Technique for Freshwater Conservation and Production. Renewable and Sustainable Energy Reviews. 54, 653-664.

[23]. Mohamad, N. R., Soh, A. S. A. M., Salleh, A., Hashim, N. M. Z., Abd Aziz, M. Z. A., Sarimin, N., Othman, A., Ghani, Z. A. (2013). Development of Aquaponic System using solar powered control pump. IOSR Journal of Electrical and Electronics Engineering (IOSR-JEEE). 8(6), 01-06.

[24]. Wikipedia (2020a). Climate change. Wikipedia the free encyclopedia. Available from https://en.wikipedia.org/wiki/Climate_change [Accessed 24/1/2020]

[25]. Wikipedia (2020b). Climate change in Vietnam. Wikipedia the free encyclopedia. Available from https://en.wikipedia.org/wiki/Climate_change_in_Vietnam [Accesed 24/1/2020]

[26]. Goetzberger, A., Zastrov, A. (1982). On the Coexistence of Solar-Energy Conversion and Plant Cultivation. Internationl Jourrnal of Solar Energy. $1(1), 55-59$

[27]. Visually (2020). Aquaponics Clycle. Visually by rockcontent. Available from https://visual.ly/community/Infographics/food/aquaponics-cycle [Acessed 24/1/2020]. 